\title{
A New Speedy Trial Standard for Barker $v$ Wingo: Reviving a Constitutional Remedy in an Age of Statutes
}

\author{
Brian P. Brooks $\dagger$
}

The Sixth Amendment right to a speedy trial ${ }^{1}$ has ancient origins in the Assize of Clarendon $(1166)^{2}$ and in the Magna Carta (1215). ${ }^{3}$ Many of the American colonies also recognized the right to a speedy trial. ${ }^{4}$ With such a venerable history, one would expect the speedy trial right to be as fundamental and extensive a guarantee as any of the other constitutionally recognized rights of the accused, such as the right to be secure against unreasonable searches and seizures ${ }^{5}$ or the right not to be compelled to incriminate oneself. ${ }^{6}$ Unfortunately, history has not played out in such a predictable fashion.

In theory, the right to a speedy trial is "fundamental."" However, because the right is so "amorphous," "slippery," and generally difficult to vindicate, ${ }^{9}$ courts have not applied a consistent legal standard in speedy trial cases. Indeed, federal appellate courts' speedy trial rulings throughout this century have portrayed the right as somehow less fundamental and more contingent than other procedural safeguards in the Bill of

$\dagger$ A.B. 1991, Harvard University; J.D. Candidate 1994, The University of Chicago.

1 "In all criminal prosecutions, the accused shall enjoy the right to a speedy and public trial ...." US Const, Amend VI.

2 See David C. Douglas and George W. Greenway, eds, 2 English Historical Documents 408 (Oxford, 1953).

3 In the Magna Carta, King John provided that "we will not . . . defer to any man either justice or right." Id, citing Magna Carta, c 29 (1215).

- See Alfredo Garcia, The Sixth Amendment in Modern American Jurisprudence 159 (Greenwood, 1992) (The states recognizing some form of speedy trial right in 1776 included Virginia, Delaware, Maryland, Massachusetts, and Pennsylvania.).

3 US Const, Amend IV. See, for example, Mapp v Ohio, 367 US 643, 649 (1961), citing McNabb v United States, 318 US 332, 339-401 (1943) (emphasizing the fundamental character of the protection against unreasonable searches and seizures).

6 US Const, Amend V. See, for example, Massiah v United States, 377 US 201, 20405 (1964) (noting that certain aspects of a defendant's right against self-incrimination are fundamental).

' Klopfer $v$ North Carolina, 386 US 213, 223 (1967).

8 Barker $v$ Wingo, 407 US 514, 522 (1972).

9 See Gregory P.N. Joseph, Speedy Trial Rights in Application, 48 Fordham L Rev $611,612(1980)$. 
Rights. ${ }^{10}$ This treatment reflects the orthodoxy that the right to a speedy trial is the one criminal procedural guarantee in the Constitution that must be limited by the countervailing demands of "public justice."11 In other words, courts have typically held-and most academic commentators have agreed-that the Sixth Amendment provides relief for defendants suffering from trial delays only where society lacks a countervailing interest in continuing to hold them for trial. ${ }^{12}$

In Barker $v$ Wingo, the Supreme Court attempted to bring some order to speedy trial jurisprudence by establishing a test for evaluating speedy trial claims. ${ }^{13}$ The Barker test-which requires courts to balance four factors-namely, the length of the delay, the reason for the delay, when the defendant asserted his right to speedy trial, and the prejudice suffered by the defendant as a result of the delay-represented no radical innovation in speedy trial jurisprudence, but was rather a consolidation of various tests already in force in the lower courts. Still, lower courts have divided sharply in their interpretations of the test. Some courts have given the four Barker factors equal weight, while others believe that the fourth factor-prejudice to the defendant-is of primary importance.

This Comment argues that both these interpretations depend on the flawed premise that society and individual defendants have inherently conflicting interests in the speed with which a defendant is brought to trial. In fact, existing interpretations of the Barker test disserve the interests that have been identified during the development of speedy trial law. In response, this Comment proposes a different approach: a "motive test" which focuses attention on the reason for trial delays. Such an inquiry would most effectively and consistently vindicate the speedy trial interests of both society and the accused.

Although most speedy trial problems today arise under either the federal Speedy Trial Act or state speedy trial statutes,

10 Prior to Klopfer, where the Supreme Court first called the speedy trial right "fundamental," the leading book on the Sixth Amendment stated that a speedy trial was "a privilege rather than a right." Francis H. Heller, The Sixth Amendment 61 (Kansas, 1951).

${ }^{11}$ This characterization first appeared in Beavers $v$ Haubert, 198 US 77, 87 (1905), which noted that the right to a speedy trial does not "preclude the rights of public justice."

12 This proposition is perhaps best established by the fact that most claims for speedy trial relief are denied. The paradigm case for granting speedy trial relief is probably Doggett $v$ United States, 112 S Ct 2686 (1992), where the petitioner, whose trial had been delayed more than 8 years, appeared to have completely reformed himself.

13407 US 514, 530 (1972). 
this Comment focuses exclusively on those instances in which a defendant seeks constitutional relief. The failure of the federal courts to develop a constitutional speedy trial test that works has given rise to these statutory remedies. Unfortunately for criminal defendants, the Speedy Trial Act is primarily designed to protect the government's interests in a speedy trial. ${ }^{14}$ This Comment argues for a revival of the constitutional remedy in order that defendants may have a meaningful right to a speedy trial.

\section{THE DEVELOPMENT OF SPEEDY TRIAL JURISPRUDENCE: BEAVERS TO BARKER}

Until relatively recently, the right to a speedy criminal trial was practically a cipher among the personal guarantees of the Bill of Rights. The Supreme Court and the federal circuit courts generally did not enforce the right because they lacked a welldeveloped means of assessing whether a defendant had been denied a speedy trial. ${ }^{15}$ Furthermore, the Court did not hold the guarantee of a speedy trial applicable to the states until $1967 .{ }^{16}$ Before Barker $v$ Wingo, lower courts that did endorse the policy objectives of the speedy trial right used meaningfully different methods to determine when the government had failed to provide a speedy trial. ${ }^{17}$ As one commentator noted, the speedy trial guarantee remained a "protean right" until the Supreme Court enunciated a legal test in $1972 .{ }^{18}$

The Supreme Court first considered the speedy trial guarantee in the 1905 case of Beavers $v$ Haubert. ${ }^{19}$ Defendant Beavers faced two separate criminal indictments, one in New York and one in the District of Columbia. The prosecutor in New York opted not to proceed with his case against Beavers and decided instead to initiate proceedings to remove Beavers to the District of Columbia for trial. Beavers objected that postponing the trial of his charges in New York violated his Sixth Amendment right

14 See text accompanying notes 84-90.

15 See Barker, 407 US at 515-16 (remarking that "in none of these [prior] cases have we attempted to set out the criteria by which the speedy trial right is to be judged").

${ }^{16}$ Klopfer, 386 US at 223.

17 See, for example, United States v Stamp, 458 F2d 759, 769 (DC Cir 1971) (balancing four Barker-like factors but considering the reason for delay only to the extent the delay was "purposeful"); United States $v$ Aberson, 419 F2d 820, 821 (2d Cir 1970) (holding that defendant's assertion of the right is an absolute prerequisite to a speedy trial claim); United States $v$ Booz, 451 F2d 719, 926 (3d Cir 1971) (holding that time is the most important element in the speedy trial balance).

${ }_{18}$ See Note, The Lagging Right to a Speedy Trial, 51 Va L Rev 1587, 1618 (1965).

19198 US 77 (1905). 
to a speedy trial. The Supreme Court rejected Beavers's claim. In an opinion that decisively shaped the speedy trial debate, the Court stated that the right to a speedy trial is neither "unqualified" nor "absolute," that the right "does not preclude the rights of public justice," and most importantly, that the right is "necessarily relative," "consistent with delays and depend[ent] upon circumstances."20

Scholars have roundly criticized the Court's premise in Beavers that defendants' interests in the speedy trial are opposed to society's interests. ${ }^{21}$ Nonetheless, over the next sixty years a strong consensus developed in the courts that the speedy trial right was more amenable to interest-balancing than other procedural protections. Federal courts after Beavers identified several interests underlying the Sixth Amendment. These interests included: providing incentives for diligence on the part of defense counsel, prosecutors, and defendants; ${ }^{22}$ discouraging purposeful or oppressive imprisonment prior to trial; ${ }^{23}$ ensuring the "orderly expedition and not mere speed" of the judicial process; ${ }^{24}$ and preventing actual prejudice to the accused. ${ }^{25}$

By the late 1960s, discussions of these numerous policy goals had completely taken over speedy trial jurisprudence. Both the lower courts and the academic literature advocated balancing tests that could capture all the diverse policy objectives of the speedy trial right. ${ }^{26}$ The Supreme Court heeded their calls when it devised the Barker test.

20 Id at 86-87.

${ }^{21}$ See, for example, H. Richard Uviller, Barker v. Wingo: Speedy Trial Gets a Fast Shuffle, 72 Colum L Rev 1376, 1378-80 (1972); Garcia, The Sixth Amendment at 157 (cited in note 4). Uviller argues that the Beavers premise (as endorsed in Barker) is wrong because all the criminal procedural guarantees in the Bill of Rights are intended to protect defendants' rights against the government; all these guarantees thus compete with societal interests. 72 Colum L Rev at 1378.

${ }_{22}$ Hedgepeth $v$ United States, 364 F2d 684, 687 (DC Cir 1966). See also Dickey $v$ Florida, 398 US 30, 38 (1970) (calling delay impermissible when merely, for the convenience of the government).

${ }^{23}$ United States $v$ Ewell, 383 US 116, 120 (1966); Pollard v United States, 352 US 354, 361 (1957). See also Williams v United States, 250 F2d 19, 21 (DC Cir 1957) (holding that the government should lose the right to prosecute if the imprisoned defendant has suffered delay attributable to factors other than the "ordinary processes of justice").

${ }^{24}$ Ewell, 383 US at 120, citing Smith $v$ United States, 360 US 1, 10 (1959).

25 Williams, 250 F2d at 21; Hedgepeth, 364 F2d at 687.

${ }^{26}$ See, for example, United States $v$ Mann, 291 F Supp 268, 270 (S D NY 1968); Note, The Right to a Speedy Trial, 20 Stan L Rev 476, 478-82 (1968). Both Mann and the Stanford Law Review Note suggest a four-pronged balancing test, taking into account the length of trial delay, the reasons for the delay, whether the defendant asserted the right to a speedy trial, and any actual prejudice suffered by the defendant. 
In Barker, the Court purported to resolve the question of how to determine a denial of a defendant's right to a speedy trial. Willie Barker was arrested for murder in Kentucky in July of 1958. In an effort to delay Barker's trial pending the conviction of an accomplice (whose testimony was considered crucial to the case against Barker), the prosecution moved for a total of sixteen continuances. Eventually, Barker was convicted in October of 1963 , largely on the strength of the accomplice's testimony. More than five years had passed between Barker's arrest and his conviction. State appellate courts denied Barker's speedy trial claim, and the lower federal courts rejected his habeas corpus plea. The Sixth Circuit ruled that Barker had waived his Sixth Amendment rights by failing to object until after the prosecution's twelfth motion for continuance. ${ }^{27}$

The Supreme Court granted certiorari to decide what criteria should be used to determine whether a defendant's speedy trial right has been violated. ${ }^{28}$ The Court then adopted a fourpronged balancing test taking into account the "[l]ength of delay, the reason for the delay, the defendant's assertion of his right, and prejudice to the defendant."29

In establishing this balancing test, the Court explicitly rejected two possible bright-line rules: one based solely on the length of delay, the other based solely on defendant's failure to demand a speedy trial. ${ }^{30}$ The Court argued that the speedy trial guarantee required a balancing approach rather than a brightline rule because the guarantee differs from other constitutional rights in three significant respects. First, the speedy trial right is more vague than other procedural rights. Second, the deprivation of the right can at times work to the accused's advantage. Third, the speedy trial right protects both the defendant's fair trial interests and the public's interest in an efficient system of justice. ${ }^{31}$ As the Court noted, "In addition to the general concern that all accused persons be treated according to decent and fair procedures, there is a societal interest in providing a speedy trial which exists separate from, and at times in opposition to, the interests of the accused." 32 1971).

${ }^{28} 407$ US at 516.

29 Id at 530 .

${ }^{30}$ Id at 523-28.

31 Id. at 519-22.

${ }_{32}$ Id at 519. 
The Barker Court stated:

We regard none of the four factors ... as either a necessary or sufficient condition to the finding of a deprivation of the right of speedy trial. Rather, they are related factors and must be considered together with such other circumstances as may be relevant. In sum, these factors have no talismanic qualities; courts must still engage in a difficult and sensitive balancing process. ${ }^{33}$

Despite the seeming simplicity of this admonition, lower courts have not settled on the proper interpretation of the Barker test. Thus, although Barker sought to clarify how the courts were to handle speedy trial claims-and although the Court effectively ratified the balancing approach already popular among courts and commentators ${ }^{34}$-Barker introduced more confusion than clarity to speedy trial jurisprudence.

\section{DIFFERING Formulations OF THE BARKER TeST}

The Second, Third, Sixth, and D.C. Circuits have adopted what might be called a "straight" balancing approach to speedy trial claims. ${ }^{35}$ Under this approach, courts give equal weight to all four Barker factors. The length of delay is often the critical factor in these cases. Indeed, a prejudicial delay is often considered a threshold requirement to the balancing inquiry. ${ }^{36}$ But after enough of a prejudicial delay has been established to allow the claim to go forward, the length of the delay is still balanced with the other factors to achieve the proper result. ${ }^{37}$ Under these cases, any construction of Barker capable of mitigating very long trial delays should therefore be rejected. The Sixth Amendment, after all, assumes that "unreasonable delays are by their

33 Id at 533.

${ }^{34}$ Fifteen years earlier, a law review note cited three of the four Barker factors as already being firmly entrenched in the law of speedy trials. Note, The Right to a Speedy Criminal Trial, 57 Colum L Rev 846, 851-58 (1957). See, for example, United States $v$ Fay, 313 F2d 620, 623 (2d Cir 1963); Buatte v United States, 350 F2d 389, 394 (9th Cir 1965); United States v Parrot, 248 F Supp 196, 202 (D DC 1965); United States v Penn, 267 F Supp 912, 913 (E D La 1967).

${ }_{35}$ See Garcia Montalvo v United States, 862 F2d 425, 426 (2d Cir 1988) (per curiam); United States $v$ Blanco, 861 F2d 773 (2d Cir 1988); Hakeem $v$ Beyer, 990 F2d 750, 759-72 (3d Cir 1993); United States $v$ White, 985 F2d 271, 275-76 (6th Cir 1993); United States $v$ Gerald, 5 F3d 563 (DC Cir 1993).

${ }^{36}$ See, for example, Blanco, $861 \mathrm{~F} 2 \mathrm{~d}$ at 777, citing United States $v$ Loud Hawk, 474 US 302, 314 (1986).

${ }_{37}$ Blanco, 861 F2d at 777. 
nature prejudicial." ${ }^{38}$ Thus, even when, for instance, a defendant cannot show prejudice, the straight balancing test holds open the possibility of a Sixth Amendment violation.

In contrast to this "straight" balancing approach, and possibly in violation of Barker's requirement to balance all four factors equally, ${ }^{39}$ the Fifth and Eleventh Circuits have adopted more of a "weighted" balancing test to better serve what they consider to be the policy goals of Barker. ${ }^{40}$ While these courts view Barker as providing a remedy for defendants who are measurably harmed by a delay, they allow prosecutors a wide degree of latitude as long as the defendant cannot show actual prejudice. A defendant must either show actual prejudice or show that all three other Barker factors weigh heavily against the government to make out a successful speedy trial claim. ${ }^{41}$

Thus, while the straight balancing approach considers all four factors (and thus allows any one factor, if sufficiently egregious, to require a reversal), the weighted balancing approach assigns a particularly heavy emphasis to the defendant's ability to show actual prejudice to his defense (often making such a finding indispensable to a successful speedy trial claim) ${ }^{42}$ The test is typically described in this way: "[Because] only two of the first three Barker factors weighed heavily against the government, the defendants were required to show actual prejudice."43

${ }^{38}$ This proposition was demonstrated most clearly in Garcia Montalvo, $862 \mathrm{~F} 2 \mathrm{~d}$ at 426, where the court acknowledged its obligation to consider the length and reason for the trial delay even where the defendant completely failed to show any particular prejudice.

${ }^{39}$ Barker, 407 US at 533 ("We regard none of the four factors ... as either a necessary or sufficient condition to the finding of a deprivation of the right to a speedy trial.").

${ }^{40}$ See Hill $v$ Wainwright, 617 F2d 375, 379 n 4 (5th Cir 1980); Ringstaff $v$ Howard, 885 F2d 1542, 1543 (11th Cir 1989).

41 The clearest case on this point is United States $v$ Mitchell, 769 F2d 1544, 1547 (11th Cir 1985), which states: "[T]he settled rule in this circuit is that unless the first three Barker factors all weigh heavily against the government, the defendants must demonstrate actual prejudice." Other cases frame the test in the obverse: if the first three factors weigh heavily against the government, then actual prejudice need not be shown. See Hill, 617 F2d at 379 n 4; Ringstaff, 885 F2d at 1543; United States v Dennard, 722 F2d 1510, 1513 (11th Cir 1984).

42 The Seventh, Ninth, and Tenth Circuits have also indicated some affinity for this weighted balancing approach. See United States $v$ Koller, 956 F2d 1408, 1415 (7th Cir 1992) (holding that, although only the reason-for-delay factor weighed in favor of the government, no speedy trial relief could be granted because actual prejudice did not weigh heavily enough in the defendant's favor); United States $v$ Mehrmanesh, 652 F2d 766, 769 (9th Cir 1980) (stating that Barker "labeled the last interest [prejudice] as the most important"); United States v Martinez, 776 F2d 1481, 1483 (10th Cir 1985) (holding that "in the absence of prejudice, we have great reluctance to dismiss an indictment for prosecutorial delay").

${ }^{43}$ Mitchell, $769 \mathrm{~F} 2 \mathrm{~d}$ at 1547. 
In other words, if the first three factors-length of delay, reason for delay, and defendant's assertion of his right-weigh heavily against the government, no showing of actual prejudice is required. As in the straight balancing cases, these courts often regard the length of delay as a "triggering mechanism"; the speedy trial guarantee does not come into play unless the delay is greater than a certain amount of time. ${ }^{44}$ But, at least until recently, once the delay passed this threshold, under the weighted approach, these courts did not inquire further into the length of delay. ${ }^{45}$ This approach may account for the fact that delays as long as eight years have failed to elicit speedy trial relief in jurisdictions applying the weighted balancing test. ${ }^{46}$

The Supreme Court took its most recent look at the speedy trial guarantee in Doggett $v$ United States. ${ }^{47}$ Doggett was indicted in February 1980 for several drug-related federal offenses. Because Doggett was then living in Bogota, Colombia, federal law enforcement officers could not directly pursue him, but they did enter his name into several major criminal databases and the INTERPOL lookout system. In September 1981, the federal agent in charge of the search for Doggett discovered that Doggett had been arrested on drug charges in Panama. Doggett was released from Panamanian custody in July 1982, a fact that the U.S. embassy in-Panama cabled to the State Department. Nonetheless, Customs officials in New York City admitted Doggett to the United States. For the next six years, federal officials made almost no effort to locate Doggett until, as a result of a routine credit check, Doggett was discovered by police and arraigned on the outstanding drug charges. Doggett, who by this time had married and was employed as a computer operations manager, objected to the arraignment on speedy trial grounds. The Eleventh Circuit upheld his conviction, relying primarily on Doggett's failure to demonstrate that the delay had prejudiced his ability to defend in 1988 against drug charges filed in $1980 .{ }^{48}$

${ }^{44}$ See, for example, Hill, $617 \mathrm{~F} 2 \mathrm{~d}$ at 378 (stating that a delay of "three years serves as a 'triggering mechanism' to invoke [any] further analysis").

${ }^{45}$ See, for example, id at 377-78. The Supreme Court dealt with this problem in Doggett $v$ United States, 112 S Ct 2686, 2690-91 (1992), where the length of delay factor was held to require a "double enquiry," viewing length first as a triggering mechanism and then as an equal factor in the balancing test. Even so, the weighted balancing test is still less likely to result in relief than a test that considers all the factors equally.

${ }_{46}$ See Bell v Lynaugh, 828 F2d 1085 (5th Cir 1987).

47112 S Ct 2686 (1992).

4 Doggett v United States, 906 F2d 573, 580-82 (11th Cir 1990). 
In an opinion by Justice Souter, the Supreme Court reversed the Eleventh Circuit. The opinion did not, however, address whether the lower court had erred by applying a weighted balancing test, requiring Doggett to show actual prejudice. Rather, the Court held that the Eleventh Circuit had incorrectly determined that the reason for delay in Doggett's case did not weigh against the government. ${ }^{49}$ In other words, Doggett was decided primarily on the lower court's misapplication of the weighted balancing test, not on the grounds that the weighted balancing approach is an invalid interpretation of Barker.

In failing to pass on the validity of the weighted balancing test, Doggett exacerbated the confusion that had developed over the proper application of the Barker test. For example, the Ninth Circuit has interpreted Doggett as eliminating a previous requirement that actual prejudice be shown. ${ }^{50}$ By contrast, a district court in the Western District of Missouri has read Doggett as allowing a prejudice requirement but imposing a separate balancing test for the prejudice factor alone. ${ }^{51}$ Other courts have similarly adopted idiosyncratic interpretations of the case. ${ }^{52}$ Doggett has therefore not provided much guidance as to how to weigh the Barker factors.

\section{CONSTItUTIONAL INTERESTS AT STAKE IN SPEEDY TRIAL JURISPRUDENCE}

Constitutional speedy trial jurisprudence consisted of interest balancing long before Barker. We should therefore not look to the Barker test alone for solutions to the underlying Sixth Amendment problem that Barker attempted to solve. Rather, it is necessary to examine the interests that have guided the past

$49112 \mathrm{~S} \mathrm{Ct}$ at 2693 . In assessing this element, the Court stated that prosecutorial negligence clearly "falls on the wrong side of the divide between acceptable and unacceptable reasons for delaying a criminal prosecution ...." Id. The lower court had stated that only "bad faith or a dilatory purpose" can cause the reason for delay factor to weigh heavily against the government. Doggett, 906 F2d at 578 .

${ }^{50}$ See United States $v$ Shell, 974 F2d 1035, 1036 (9th Cir 1992).

51 See United States $v$ Shelton, 820 F Supp 461, 466-67 (W D Mo 1992).

${ }^{52}$ See, for example, United States $v$ Vassell, 970 F2d 1162, 1165 (2d Cir 1992), cert denied as Moore $v$ United States, 113 S Ct 627 (1992) (citing Doggett for the proposition that the need to show actual prejudice varies inversely with the length of delay); Hakeem $v$ Beyer, 990 F2d 750, 763 (3rd Cir 1993) (interpreting Doggett to mean that presumptive prejudice, as distinct from "particularized prejudice," increases with the length of delay); United States v Anagnostou, 974 F2d 939, 942 n 1 (7th Cir 1992), cert denied, $113 \mathrm{~S} \mathrm{Ct}$ 1943 (1993) (reading Doggett to mean that prosecutorial negligence, as distinct from bad faith, weighs against the government only in cases where the delay is extremely long). 
century of speedy trial decisions and that the Barker test was designed to serve.

\section{A. Constitutionally Recognized Interests}

Perhaps the most widely accepted premise of speedy trial law is that both society and accused individuals have meaningful and meaningfully different stakes in the speed with which criminal cases are brought to trial. ${ }^{53}$ The Barker Court, for instance, suggested that societal interests exist "separate from, and at times in opposition to, the interests of the accused." While some scholars criticize this distinction on the grounds that all Bill of Rights guarantees, as personal guarantees, are in conflict to some degree with societal interests, ${ }^{55}$ none deny that the conflict exists, or that courts take account of it. The conflict therefore bears closer examination.

\section{Individual interests.}

In the debate over how to interpret the speedy trial guarantee, courts and scholars often juxtapose the defendant's and society's interest in a speedy trial. The Sixth Amendment, however, is not a safeguard for such strategic interests, but rather for constitutional interests. Criminal defendants have three distinct constitutional interests in receiving a speedy trial: preventing oppressive pretrial incarceration, minimizing public obloquy, and preventing prejudice against the defendant at trial. ${ }^{56}$ When these interests are shortchanged by delay, the Sixth Amendment is violated, notwithstanding any strategic advantage the defendant may gain.

The defendant's first interest in the right to a speedy trial is avoiding undue and oppressive pretrial incarceration. ${ }^{57}$ Just as protecting political speech is sometimes thought to be at the "core" of the First Amendment, preventing government abuse of the power of imprisonment is often thought to be at the core of

${ }^{53}$ See, for example, Beavers, 198 US at 87 (noting the speedy trial right secures rights of a defendant, but does not preclude the rights of public justice); Barker, 407 US at 519-22; Dickey v Florida, 398 US 30, $42-43$ (1970) (Brennan concurring) (stating that "[j]ust as a delay may impair the ability of the accused to defend himself, so it may reduce the capacity of the government to prove its case").

54 Barker, 407 US at 519.

${ }_{55}$ See, for example, Garcia, The Sixth Amendment at 157 (cited in note 4).

56 See Barker, 407 US at 532.

57 See id; Dickey, 398 US at 41, citing Ewell, 383 US at 120. 
the speedy trial guarantee. The Sixth Amendment was adopted against a backdrop of English and early colonial practice in which criminal prosecutions had been conducted with "unfairness," "brutality," and the "savage satisfaction" of the courts in their oft-exercised power of life and death over criminal defendants. ${ }^{58}$

The defendant's second interest in the speedy trial right lies in the reduction of anxiety and concern accompanying public accusation. As the Supreme Court noted in United States $v$ Marion, the "public obloquy" and "anxiety" accompanying an arrest or indictment implicate Sixth Amendment concerns just as surely as incarceration does:

[T] he major evils protected against by the speedy trial guarantee exist quite apart from actual or possible prejudice to an accused's defense. To legally arrest and detain, the Government must assert probable cause to believe the arrestee has committed a crime. Arrest is a public act that may seriously interfere with the defendant's liberty, whether he is free on bail or not, and that may disrupt his employment, drain his financial resources, curtail his associations, subject him to public obloquy, and create anxiety in him, his family and his friends. ${ }^{59}$

The third individual interest lies in preserving the accused's ability to defend against pending criminal charges. ${ }^{60}$ Although this interest was not as central to the original understanding of the Sixth Amendment as the interest in preventing oppressive incarceration, ${ }^{61}$ modern judicial opinions have accorded it the most attention. Trial prejudice, according to the Court in Doggett, is the paramount interest protected by the speedy trial guaran-

58 Heller, The Sixth Amendment at 13 (cited in note 10).

59 404 US 307, 320 (1971). In recognizing this interest, the Marion Court relied on a similar expression of concern over the possibility of personal anxiety and public ostracism in Klopfer $v$ North Carolina, 386 US 213 (1967). The Klopfer Court had held that a professor at Duke University charged with criminal trespass stated a valid claim for speedy trial relief even though he had not been incarcerated during the pendency of his indictment. Id at 221-22.

${ }_{60}$ See Ewell, 383 US at 120 (stating that the speedy trial right serves to "limit the possibilities that long delay will impair the ability of an accused to defend himself").

${ }_{61}$ The strongest evidence that trial prejudice was not the most central concern of the speedy trial guarantee is the Supreme Court's statement one year before Barker that "the major evils protected against by the speedy trial guarantee exist quite apart from actual or possible prejudice to an accused's defense." Marion, 404 US at 320. 
tee-more serious, the Court implied, than either oppressive pretrial incarceration or public scorn. ${ }^{62}$

\section{Societal interests.}

Society also has three distinct interests in ensuring that defendants receive a speedy trial. The first interest is in the effective prosecution of criminal cases. ${ }^{63}$ Given that prosecutors often benefit from trial delays-especially in complex, multi-defendant actions ${ }^{64}$-one might view a speedy trial as anathema to effective prosecution. Yet "effective prosecution" does not consist of convicting all defendants through any means possible. Rather, "[t]he Speedy Trial Clause [] serves the public interest by penalizing official abuse of the criminal process and discouraging official lawlessness." "Effective prosecution" thus requires that the state pursue criminal indictments vigorously and swiftly within the context of a fair judicial system. ${ }^{66}$ This is not to say that society can never have a constitutionally cognizable interest in trial delay; the Supreme Court has never suggested that delay while the prosecution gathers evidence or while a co-conspirator is prosecuted would violate the Sixth Amendment. Nonetheless, as Justice Brennan explained in Dickey $v$ Florida, society's Sixth

62 Six justices in Doggett endorsed the proposition that preventing unfair prejudice to an accused's ability to present a defense is "the most serious" individual interest protected by the speedy trial guarantee. $112 \mathrm{~S} \mathrm{Ct}$ at 2692, quoting Barker, $407 \mathrm{US}$ at 532 . Note that trial prejudice is not synonymous with the prejudice element of the Barker test. Rather, it is one of the interests (along with oppressive pretrial incarceration, and undue anxiety and concern of the accused) meant to be captured by the prejudice element of the Barker test.

Justice Thomas, joined by two other Justices, questioned whether preventing trial prejudice could legitimately be understood as an aim of the Sixth Amendment. $112 \mathrm{~S} \mathrm{Ct}$ at 2695-97 (Thomas dissenting). Thomas suggested that there are two conflicting lines of authority regarding the individual interests protected by the speedy trial guarantee. One line, culminating in the language of Barker, recognizes trial prejudice as a concern within the purview of the Sixth Amendment. See Barker, 407 US at 532; Smith v Hooey, 393 US 374, 377-78 (1969); Ewell, 383 US at 120. The second line recognizes only incursions into defendants' liberty as justifications for speedy trial relief. See Marion, 404 US at 321-22; United States $v$ Loud Hawk, 474 US 302, 312 (1986). Thomas rejected the former line of authority but endorsed the latter. Doggett, $112 \mathrm{~S} \mathrm{Ct}$ at 2697 (Thomas dissenting).

63 See Dickey, 398 US at 42 (Brennan concurring).

64 In Barker, for instance, prosecutors waited to try Barker until they obtained the conviction of his accomplice. The accomplice's testimony was considered essential to the prosecution's case against Barker. 407 US at 516.

65 Dickey, 398 US at 43 (Brennan concurring).

${ }_{66}$ See id (noting that the right to a speedy trial protects society's interest in prosecuting-not persecuting-the accused). 
Amendment interest is and should be aligned with speedier trials. ${ }^{67}$

Second, society has an interest in preventing an accused who is not incarcerated from committing additional criminal acts while awaiting trial. ${ }^{68}$ Speedy trial claims may arise when defendants are free as well as when they languish in jail. For example, the defendant in Doggett was free for the eight and a half years between the time of his indictment and his trial. ${ }^{69}$ The government's negligence in pursuing Doggett thwarted society's legitimate interest in bringing drug dealers to justice, and left open the possibility that this particular defendant could have continued dealing and smuggling drugs for the entire period of his extended trial delay. ${ }^{70}$

Society's third speedy trial interest lies in reducing the wasted cost of pretrial incarceration for defendants who will ultimately be acquitted. Not only does society pay the actual costs of incarceration, but society also loses the benefit of an additional tax-paying wage earner. ${ }^{71}$ Some defendants whose trials are unconstitutionally delayed are likely to be found innocent. Society thus has a purely economic interest, quite apart from its metaphysical interests in justice, in seeing that these defendants are tried and released as quickly as possible.

This Section has described the constitutionally significant interests of individual criminal defendants on the one hand and those of society on the other. Implicit in this description is the idea that the Sixth Amendment does not recognize the more pedestrian consideration of which party will prevail in a particular case. The fact that a delayed trial may increase the probability of a conviction does not necessarily further any constitutionally recognized societal interest. Similarly, even if trial delays improve a defendant's chances of acquittal, the defendant's constitutional interests would nonetheless be harmed. Neither society nor the criminal defendant has a constitutionally protected in-

67 Id at 42.

68 Id.

69 Doggett, 112 S Ct at 2689-90.

70 In fact, Doggett was living "a normal, productive, and law-abiding life" by the time he was finally brought to trial. At that point, the former drug smuggler had married, earned an associate's degree at college, obtained employment, bought two houses, filed income tax returns, registered to vote, and never attempted to conceal his identity or whereabouts. See Doggett, 906 F2d at 577.

7 See Barker, 407 US at $520-21$. Society must also often support the dependents of the accused as well. Id at 521. 
terest in winning a given case; what each has are the very particular interests specified above.

\section{B. Sub-Constitutional Interests}

Notwithstanding the idea that neither society nor the accused defendant has a constitutional interest in a delayed trial, it is still a basic premise of speedy trial jurisprudence that either might have a non-constitutional, strategic interest in such a delay. Depending on the circumstances, either the prosecutor or the defendant may stand to benefit from trial delay.

Often, delay strengthens the prosecution's case. ${ }^{72}$ The prospects of developing additional testimony, encouraging plea bargains, negotiating grants of immunity, or convicting co-conspirators all encourage prosecutors to delay trials. Additionally, in an age when prosecutorial resources are stretched to their limit, delays reduce the need to prioritize among pending cases. ${ }^{73}$

Like prosecutors, defendants can also have strong incentives to delay trials. ${ }^{74} \mathrm{~A}$ defendant's most obvious interest in trial delay arises when the trial is highly publicized or politically charged. In such a case, the defendant might want to wait to be tried until tempers have calmed and publicity has faded. ${ }^{75} \mathrm{De}$ fendants might also want to delay in the hope that prosecution witnesses will forget enough details to create the reasonable doubt needed for acquittal.

Barker implicitly recognizes these incentives for delay and can be applied to counter them in several ways. First, the Barker test includes an inquiry as to whether, and when, the defendant seeking dismissal of the charges against him has invoked his

72 That is vividly illustrated by repeated assertions that the Sixth Amendment allows for greater delay in complex conspiracy cases than it does in simpler cases. See, for example, Barker, 407 US at 531 ("The delay that can be tolerated for an ordinary street crime is considerably less than for a serious, complex conspiracy charge.").

${ }^{73}$ In drug prosecutions, for example, it may be so difficult for the government to locate particular defendants that prosecutors are simply better off prosecuting those defendants they happen to locate and waiting until others show up before prosecuting them. This is so even when the missing defendants are not purposely evading law enforcement authorities. See, for example, Doggett, 112 S Ct 2686.

74 This claim has practically become a mantra for those who support a narrow reading of the speedy trial guarantee. In the pre-Barker cases, courts advocating the "demandwaiver" rule often invoked this proposition in assuming that delay benefits a defendant. See Barker, 407 US at 524-26.

75 Defendants in these cases might have a constitutional interest in delay under the impartial jury clause of the Sixth Amendment. However, the speedy trial right includes no such constitutional interest. 
speedy trial right. ${ }^{76}$ Second, courts that apply the weighted balancing version of Barker use the test's fourth prong-prejudice to the defendant-to preserve the government's ability to prosecute long-delayed cases when the delay has not prejudiced the defendant.

Unfortunately, the Barker test can just as well be used to reinforce these strategic interests as to counteract them. For example, under the weighted balancing test, prosecutors can benefit from trial delays as long as they do not prejudice the defendant. ${ }^{77}$ However, the Sixth Amendment's speedy trial guarantee only protects the procedural fairness of a trial-not either side's interest in winning. Yet without a coherent interpretation of Barker, the Barker test can be read to respect strategic incentives (which may lead to trial delays) that conflict with constitutional interests (which may not).

\section{C. "Severe" Remedies}

Not only do current speedy trial doctrines grant relief infrequently, they may also grant relief in the wrong circumstances. Based on a rigorous analysis of the policies underlying the speedy trial right, one can construct an interpretation of the Barker test that results in relief when delay contravenes these policies and denies relief in other cases. This task is especially important because of the nature of the remedy for speedy trial violations.

Only one remedy can cure a speedy trial violation: dismissal with prejudice. ${ }^{78}$ The dismissal requirement, like so many other elements of speedy trial law, is rooted in the fundamental judicial belief that the speedy trial right is different from other criminal procedural rights. Chief Justice Burger, writing for the Court in Strunk $v$ United States, stressed that a speedy trial violation, unlike, for example, the failure to afford a public trial or an im-

76 This inquiry comprises the third prong of the Barker test. 407 US at 531. Federal courts have often been ruthless in their consideration of the defendant's assertion of his speedy trial right. The appellate court in Barker, for example, affirmed the defendant's conviction solely because he had waited too long to assert his right. Barker, 442 F2d 1141 (6th Cir 1971). And in one Fifth Circuit case, the court held that although the defendant's eight-year delay was "presumptively prejudicial," he nonetheless did not state a claim for relief largely because he had failed to assert his speedy trial claim until eight years after indictment. Bell v Lynaugh, 828 F2d 1085, 1094 (5th Cir 1987).

77 See text accompanying notes 39-46.

${ }^{78}$ See Strunk v United States, 412 US 434, 440 (1973), citing Barker, 407 US at 522. 
partial jury, cannot be corrected by granting a new trial. ${ }^{79}$ Thus, although dismissal "is more serious than an exclusionary rule or a reversal for a new trial[,] . . . it is the only possible remedy."

Because this remedy is absolute, courts tend to apply the speedy trial right reluctantly. ${ }^{81}$ Courts often seem to avoid the "unsatisfactorily severe remedy of dismissal." 82 Other courts have pointed to the strict remedy as justification for requiring that the defendant show actual prejudice. ${ }^{83}$ While this Comment argues that the Barker test should be interpreted in a way that recognizes the vitality of the speedy trial right as a protection for criminal defendants, any standard that furthers such an interpretation must take into account the extreme remedy that the Supreme Court has mandated for all speedy trial violations.

\section{The Advantages of A Motive Test}

\section{A. A Lesson from the Speedy Trial Act}

The Barker test can only be effective to the extent that it protects constitutional speedy trial interests and minimizes strategic incentives for delay. Recall that both prosecutors and defendants have interests in speedy trials and interests in delay, but the Sixth Amendment only grants constitutional status to interests associated with speedy trials. An effective interpretation of Barker $v$ Wingo, therefore, must promote speedy trial interests without promoting other merely strategic interests.

Judicial interpretations of the Speedy Trial Act ${ }^{84}$ reveal that speedy trial interests can be effectively separated from delay incentives. Congress intended the Speedy Trial Act to compensate for the "ill-defined constitutional criteria" of the speedy trial guarantee, ${ }^{85}$ as well as to give greater substance to the societal

79 Strunk, 412 US at $438-39$.

80 Barker, 407 US at 522.

${ }^{81}$ See, for example, United States $v$ Jones, 524 F2d 834, 852 (DC Cir 1975) (expressing reluctance to apply such a "draconian remedy"); State $v$ Alfred, 337 S2d 1049, 1057 (La 1976) (refusing to apply dismissal remedy "overzealous[y]"). See also Joseph, 48 Fordham L Rev at 619 (cited in note 9).

${ }^{82}$ See, for example, Hill $v$ Wainwright, 617 F2d 375, 377 (5th Cir 1980). The Hill court cited Barker for the proposition that dismissal was an "unsatisfactorily severe" remedy, but left out the next sentence of Barker, where the Supreme Court stated that "it is the only possible remedy." See Barker, 407 US at 522. banc).

See, for example, Ringstaff $v$ Howard, 885 F2d 1542, 1544-45 (11th Cir 1989) (en

84 Speedy Trial Act of 1974, Pub L No 93-619, 88 Stat 2076, codified at 18 USC $\S \S$ 3161-74 (1988 \& Supp 1992).

${ }_{85}$ Garcia, The Sixth Amendment at 174 (cited in note 4). See also Speedy Trial Act, 
interest in speedy trials. ${ }^{86}$ The underlying purposes of the Speedy Trial Act are so similar to those underlying the Sixth Amendment that at least one scholar has argued that the constitutional ends of the Sixth Amendment can best be achieved through statutory remedies. ${ }^{87}$ The reason for such a recommendation is that the criteria for framing a successful Speedy Trial Act claim are much clearer than the Barker criteria, which, as we have seen, are applied inconsistently throughout the federal courts. ${ }^{88}$ Perhaps, then, a glimpse at the statutory speedy trial standard can provide insight as to what kind of standard would best bring a uniform interpretation to the Barker test in the constitutional context.

In a recent Speedy Trial Act decision, the Tenth Circuit provided a fairly dramatic picture of how courts separate the interests protected by the speedy trial right from the incentives that may lead one party or the other to seek trial delay:

The Government contends that [the defendant] knowingly waived his right to a speedy indictment. This contention fallaciously assumes a defendant has the authority to waive the speedy indictment provision. The right to a speedy indictment belongs to both the defendant and society. Therefore, provisions of the Speedy Trial Act cannot be waived by a defendant acting unilaterally because it would compromise the public interest in speedy justice. ${ }^{89}$

This application of the Speedy Trial Act demonstrates one way to create positive incentives for prosecutors to bring cases to trial quickly and vindicate defendants' constitutional interests in speedy trials. ${ }^{90}$ In theory, the courts respect speedy trial inter-

HR Rep No 93-1508, 93d Cong, 2d Sess, reprinted in 1974 USCCAN 7401, 7402 (noting the Act was intended to "give effect to the Sixth Amendment right to a speedy trial"); United States $v$ Mehrmanesh, 652 F2d 766, 769 (9th Cir 1980) (noting the Speedy Trial Act was passed partly because Congress was dissatisfied with Barker).

${ }^{86}$ See 1974 USCCAN at 7402 (noting the purpose of the Act is to reduce crime and the danger of recidivism).

${ }_{87}$ See Joseph, 48 Fordham L Rev at 647-48 (cited in note 9).

s8 Joseph suggests that the constitutional speedy trial right is lost in the "fact-laden morass" of judicially created constitutional doctrine. Id at 648 .

${ }^{89}$ United States v Saltzman, 984 F2d 1087, 1091 (10th Cir 1993) (citations omitted), cert denied, 113 S Ct 2940 (1993). The federal Speedy Trial Act may at first seem an inapposite example because it was adopted for the express purpose of vindicating societal speedy trial interests, while the Sixth Amendment is often thought to confer rights on individuals. But as discussed, the Supreme Court has consistently interpreted the Sixth Amendment speedy trial guarantee as protecting both individual and societal interests.

${ }^{\infty 0}$ Of course, because the Speedy Trial Act applies only to federal prosecutions, see 
ests while declining to recognize interests in delay. For example, prosecutors must bring cases quickly, despite any delay tactics by defendants, or have their cases dismissed. The question remains whether a similar approach could work within the limits of the Barker test.

\section{B. Shortcomings of Existing Approaches}

The federal courts have applied two basic interpretations of Barker: the straight balancing test and the weighted balancing test. Neither effectively vindicates the constitutional interests at stake, and both are vulnerable to manipulation that favors strategic interests-interests that arguably have no place in speedy trial analysis. This Section proposes a new legal standard in order to address these problems better.

\section{The straight balancing approach.}

In effect, the straight balancing test treats each of the Barker factors as a proxy for one or more of the underlying interests protected by the Sixth Amendment. ${ }^{91}$ In so doing, this test can vindicate the constitutional interests of criminal defendants. Still, flaws remain. First, it does not treat the threat of prejudice as seriously as does the weighted test. Prejudice to an accused person's defense is at the core of the speedy trial guarantee, ${ }^{92}$ and because the straight balancing test weighs prejudice in the same manner as the other interests at stake, it may not give enough weight to this crucial factor. But since this approach at least occasionally results in relief for speedy trial petitioners, ${ }^{93}$ it may better serve the other two constitutional interests of defendants, namely, preventing undue incarceration and reducing the public scorn that accompanies an indictment. Moreover, it may be that because the straight balancing test results in relief more frequently than the weighted test, ${ }^{94}$ the former test is in

United States $v$ Mills, 964 F2d 1186, 1188-89 (DC Cir 1992) (en banc), cert denied, $113 \mathrm{~S}$ Ct 471 (1992), even the most liberal interpretation of the Act will not help defendants in state prosecutions, though states often have their own statutory remedies.

${ }_{91}$ See Barker, 407 US at 530-33 (discussing the underlying policies justifying each of the factors in the balancing test).

${ }_{92}$ See Doggett, 112 S Ct at 2692.

93 See, for example, United States $v$ Shelton, 820 F Supp 461 (W D Mo 1992); United States $v$ Zabady, 546 F Supp 35 (M D Pa 1982); Moore v De Young, 391 F Supp 111 (D NJ 1974), rev'd on other grounds, 515 F2d 437 (3rd Cir 1975).

${ }^{94}$ Only once has a "weighted" circuit (the Fifth or Eleventh) dismissed an indictment on constitutional speedy trial grounds since Barker. See Prince v Alabama, 507 F2d 693 
practice actually more advantageous to defendants whose main concern is trial prejudice.

The greatest drawback to the straight balancing test is that it manages defense and prosecutorial incentives for delay in an undesirably contingent way. The prosecutor's incentive to bring a case to trial quickly will vary according to the defendant's behavior. The fact that the third Barker element (the defendant's assertion of the right) is accorded as much weight as the fourth element (actual prejudice) strengthens the defendant's incentive to request a speedy trial at the earliest opportunity and minimizes his incentives for strategic behavior. But the longer the defendant waits to request a speedy trial (for example, to wait for adverse publicity to die down, to finish gathering exculpatory evidence, or even because the defendant is unaware that charges are pending at all), the longer the prosecutor can delay the trial with impunity. The likelihood that the case will be dismissed on speedy trial grounds varies directly with the speed with which the defendant asserts his Sixth Amendment rights.

\section{The weighted balancing test.}

The weighted balancing test uses the first Barker element-the length of trial delay-as a "triggering mechanism"; only if the delay is long enough will the court inquire into the other three factors. ${ }^{95}$ The length of delay required to trigger a Sixth Amendment inquiry depends on the nature of the prosecution. In general, trial must be delayed for at least eight months. ${ }^{96}$ If the length of delay element is satisfied, courts then analyze the reason for the delay, whether the defendant asserted the Sixth Amendment right at the earliest available opportunity, and the degree of actual prejudice suffered as a result of the delay. ${ }^{97}$ The actual prejudice inquiry, however, receives special attention. Actual prejudice is required for a successful speedy trial claim unless all three other Barker elements are shown to "weigh[ ] heavily against the government."

(5th Cir 1975).

${ }^{95}$ Ringstaff, 885 F2d at 1543. In Barker, the Supreme Court stated that the length of delay element is only "to some extent" a triggering mechanism. 407 US at 530.

${ }_{96}$ See Joseph, 48 Fordham L Rev at 623 n 71 (cited in note 9) (collecting cases).

97 See, for example, Ringstaff, 885 F2d at 1543.

98 United States $v$ Mitchell, $769 \mathrm{~F} 2 \mathrm{~d} 1544,1547$ (11th Cir 1985), citing United States $v$ Dennard, 722 F2d 1510, 1513 (11th Cir 1984). 
The weighted balancing approach differs from the straight approach in two important respects: first, the length-of-delay element of Barker is treated as a triggering mechanism; ${ }^{99}$ and second, a criminal defendant does not stand a reasonable chance of winning speedy trial relief unless he shows actual prejudice. ${ }^{100}$ Thus understood, the straight balancing test tends to grant relief more liberally than its weighted-balancing cousin. For example, in a case where the trial was long delayed but not outrageously so, the reason for delay was prosecutorial negligence (which weighs less heavily against the government than actual misconduct ${ }^{101}$ ), the defendant asserted his right to a speedy trial at the first moment he learned of his accusation, and no actual prejudice was shown may conceivably result in relief under the straight balancing test, whereas it may not under the weighted approach.

The weighted balancing approach does not adequately serve the constitutional interests Barker aims to protect. Admittedly, the weighted approach appears highly protective of the defendant's ability to defend himself; trial prejudice forms the core of the weighted approach. ${ }^{102}$ In practice, however, the weighted balancing test almost never results in speedy trial relief for even the most egregious delays. ${ }^{103}$ No matter how long the trial delay, a defendant will never obtain relief without a showing of prejudice unless he can show that both of the other two Barker factors weigh heavily against the government, a requirement that is almost never met in the reported cases. Thus, the weighted balancing test does not really protect the defendant's interest in preventing undue and oppressive incarceration. By the same token, the test fails to take into account the defendant's interest in reducing the public obloquy accompanying

${ }^{99}$ See, for example, United States v Vassell, 970 F2d 1162, 1164 (2d Cir 1992) (refusing to consider the remaining Barker factors unless the length of delay is "presumptively prejudicial"); United States $v$ Blanco, 861 F2d 773, 777 (2d Cir 1988) (using length of delay as a trigger, then balancing the remaining factors); Rayborn $v$ Scully, $858 \mathrm{~F} 2 \mathrm{~d} 84$, 89 (2d Cir 1988) (same).

100 See cases cited in note 103.

101 See Doggett, $112 \mathrm{~S} \mathrm{Ct}$ at 2693.

102 For example, under the weighted approach, as long as the triggering length of delay was satisfied, a defendant who both failed to invoke his speedy trial right and who was unable to show prosecutorial misconduct could still receive relief if he suffered prejudice to his defense.

${ }_{103}$ See, for example, Bell $v$ Lynaugh, 828 F2d 1085 (5th Cir 1987) (relief denied for an eight-year delay); Hill $v$ Wainwright, 617 F2d 375 (5th Cir 1980) (relief denied for a threeyear delay); Ringstaff, 885 F2d 1542 (relief denied for a 23-month delay). 
criminal accusation, because the length of delay factor is almost never determinative.

With regard to society's speedy trial interests, the weighted approach only protects society's interest in effective prosecution. Even then, the weighted approach only serves this interest because the prosecutor's interest in winning trials is closely aligned to society's interest in putting offenders behind bars. When delay does not hamper a prosecutor's potential for trial success, however, the weighted approach leaves society's interests in preventing recidivism unprotected because the prosecutor can either strategically delay or simply neglect to prosecute, without fear of dismissal. In such a case-where, for example, the prosecution simply seeks to harass the defendant-the link between the prosecutor's interest in winning the trial and society's interest in quickly incarcerating criminals is severed. Additionally, when the defendant is incarcerated for the period of delay, society has to spend public resources on the incarceration of possibly innocent defendants.

Finally, the weighted balancing test creates a set of incentives running in favor of trial delay rather than speedy prosecution. On the one hand, the weighted approach provides no reward to the defendant who vigorously asserts his right to a speedy trial. The only element that effectively counts under the weighted test is actual prejudice, so defendants who have a present incentive to delay will wait to assert their speedy trial right until they have suffered actual prejudice. Because the weighted balancing test does not give any exaggerated weight to whether the defendant has asserted his right, a defendant can try to beat the system in two ways: first, by failing to assert his speedy trial right during the time he perceives a speedy trial to be detrimental to his ability to win at trial; and second, by moving for dismissal as soon as he suffers actual prejudice. The defendant's constitutionally protected interests-such as preventing undue incarceration and public obloquy-thus become subjugated to his strategic interest in improving his odds at trial.

Nor does the weighted approach provide any incentive for the prosecutor to seek a speedy trial. Because courts view the reason for delay as less important than actual prejudice, the strategic prosecutor can "punish" the recalcitrant defendant by moving for multiple continuances that will likely be granted as long as the prosecutor can show that the defendant's ability, say, to produce key witnesses, is intact. Society's interests in speedy justice thus become secondary to the prosecutor's interest in trial delay. 
In sum, both the "straight" and the "weighted" interpretations of Barker leave many of the concerns underlying the speedy trial right unaddressed. At the same time, these interpretations serve other interests that are irrelevant, even counterproductive, for the purposes of the Sixth Amendment. Both approaches should be abandoned in favor of the motive test suggested by this Comment.

\section{A New Approach: The Motive Test}

The interests underlying the Sixth Amendment would be best served if courts adopted a balancing test that placed extra weight on the reason for delay rather than prejudice. As under the existing weighted balancing test, length of delay should operate as a triggering mechanism. Under this test, relief would be granted in each of two circumstances: first, when the reason-fordelay factor is found to weigh heavily against the government, ${ }^{104}$ or second, when the defendant's assertion of the right and actual prejudice both weigh heavily against the government.

Because of the focus on the reason for delay, this approach can be labelled the "motive" test. The "motive" label does not imply a free-ranging judicial inquiry into the psychological motivations driving either prosecutors' or defendants' litigation behavior. Such an inquiry would certainly be costly, if not fruitless.

The motive test has its roots in concurring opinions in the speedy trial decisions United States $v$ Ewell, ${ }^{105}$ Dickey v Flori$d a,{ }^{106}$ and United States $v$ Marion. ${ }^{107}$ In Ewell, Justice Brennan rejected the Court's ad hoc balancing of interests as "approval of a course of government conduct" that he found "most oppressive." 108 Justice Brennan felt that even though the facts of the case showed no prejudice at all, the Court should not adopt any legal test that appeared to endorse prosecutorial coercion or harassment. ${ }^{109}$ In Dickey, Justice Brennan underscored the idea

${ }_{10 s}$ For the reason for delay to weigh heavily against the government, a defendant must show actual prosecutorial bad faith or misconduct and not mere negligence. A clear showing of governmental negligence counts in a defendant's favor to an important but lesser extent. See Doggett, $112 \mathrm{~S}$ Ct at 2693.

${ }_{105} 383$ US 116, 125-26 (1966) (Brennan concurring).

106398 US 30, 43 (1970) (Brennan concurring).

107404 US 307, 334 (1971) (Douglas concurring).

${ }^{108}$ Ewell, 383 US 116 at 125 (Brennan concurring).

${ }_{109}$ Id at 126. Brennan did not distinguish in his concurring opinion between the defendant-appellees' speedy trial and due process claims, but his reasoning applies equally well to both claims. 
that "deliberate governmental delay" is one of the most significant dangers addressed by the Sixth Amendment-so significant, in fact, that Brennan characterized the prevention of such governmental misconduct not as an individual defendant's interest but as a "common interest."110 Finally, in Marion, Justice Douglas cited Justice Brennan's Dickey opinion for the proposition that the length of delay tolerable in a particular case depends largely on the reason for the delay. ${ }^{11}$

The motive test better protects defendants' speedy trial interests than does the weighted test because the motive test prevents prosecutors from oppressively incarcerating defendants when the delay has no prejudicial effect. The motive test is thus similar to the straight balancing test in that it does not require that all three other Barker factors weigh heavily against the government. The innovation of the motive test is essentially that a showing of improper governmental motive is deemed sufficient-not necessary-to establish a speedy trial claim:

The motive test also strongly protects society's speedy trial interests. Society's interest in reducing recidivism can only be protected by a speedy trial test that provides an incentive for prosecutorial diligence and good faith. Because the motive test would grant relief more frequently than the weighted balancing test, the motve test furthers society's interests in reducing recidivism by defendants awaiting trial and in reducing expenditures wasted while preventing the unwarranted losses associated with innocent defendants. Nor does the motive test hinder society's ability to prosecute effectively, because the test only results in the dismissal of cases in which delay is attributable to prosecutorial bad faith, misconduct, or gross negligence. ${ }^{112}$ Unlike the straight balancing test, the motive test will usually not call for the dismissal of a fair prosecution. ${ }^{113}$

The motive test also manages the defense and prosecutorial incentives for delay more productively. The motive test reduces a defendant's incentive to delay assertion of the speedy trial right. When the state has not acted out of an improper motive, early

110 Dickey, 398 US at 43 (Brennan concurring).

III Marion, 404 US at 334 (Douglas concurring).

112 Recall that the government's repeated failure to apprehend Doggett was characterized as negligent. Doggett, $112 \mathrm{~S} \mathrm{Ct}$ at 2691.

${ }^{113}$ One might fear such an occurrence under the straight balancing test because a very small showing of government negligence, together with a delay of moderate length, an early assertion by the defendant of his speedy trial right, and a small amount of prejudice could conceivably result in dismissal. 
assertion will count in the defendant's favor; conversely, when the government has acted improperly, the defendant gains nothing by seeking delay of his trial (for his chances of gaining dismissal are already strong). Under the weighted balancing test, defendants have an incentive to delay because the degree of actual prejudice increases as time passes. Eventually the prejudice requirement becomes self-actuating, and the strategic defendant receives a windfall in the form of dismissal.

At the same time, the motive test forces the government to prosecute with reasonable speed irrespective of any action taken by the defendant. The motive test is thus superior to the weighted balancing approach because the prosecution cannot oppress or coerce defendants by delaying their trials to the point of actual prejudice. So doing would cause the reason for delay to weigh heavily against the government. Further, the motive test separates the prosecution's incentives from the defendant's behavior, so that the speed with which the prosecution brings a case to trial no longer depends on the speed with which the defendant asserts his speedy trial rights. If a defendant shows that a prosecutor engaged in such strategic behavior, the defendant would state a good claim for dismissal under the motive test. The motive test, in other words, provides an independent incentive for the prosecutor to proceed with reasonable speed.

Two applications of the motive test provide a clearer view of its operation. In United States $v$ Lustman, a case with a common speedy trial fact pattern, the Second Circuit denied relief under something like the straight balancing test. ${ }^{114}$ Lustman was indicted for mail fraud, but he was not tried on the charges for more than five years. Lustman caused one and a half years of the delay by making multiple motions for continuances and by submitting more information to the prosecutor in hopes the prosecution would drop the case. While the remaining four years were caused by "undue" neglect on the prosecutor's part, the defendant did not make any speedy trial motion until the entire five-and-ahalf-year period had elapsed. ${ }^{115}$ Further, Lustman had not shown that the delay had impaired his ability to defend.

Because only the length of the delay weighed heavily against the government, a straight balancing test would (and did) come out against the defendant. The motive test, however, would focus on the fact that four years of trial delay were attributable to

114258 F2d 475 (2d Cir 1958).

115 Id at 477. 
nothing more than the government's negligence and would accordingly result in dismissal. The fact that Lustman was free for the entire period of delay-rendering him able to commit further crimes-underscores the need to spur quicker prosecution in cases like his.

The motive test will not, of course, result in relief for all speedy trial petitioners-nor should it. The motive test is designed to provide relief in the right cases, not just in more cases. A second and equally common set of facts appeared in Bell $v$ Lynaugh, where the Fifth Circuit denied relief under the weighted balancing test. ${ }^{116}$ Bell's trial was delayed for eight years. The entire delay, however, was due to the defendant's own desire to postpone trial on one charge until all avenues of appeal from conviction for another charge had been exhausted. Bell did not make a speedy trial motion until eight years had passed, and he failed to demonstrate actual prejudice as a result of the delay. The weighted balancing test therefore would (and did) deny relief, since neither actual prejudice nor all three other Barker factors weighed heavily against the government. The motive test would also deny relief here because Bell's own behavior had caused the entire delay.

\section{CONCLUSION}

The policy underpinnings of Barker $v$ Wingo should be taken seriously. While it is often said that the interests of defendants diverge from the interests of society, there is one common thread: speedier trials can protect both societal and individual interests. Individual defendants and prosecutors may occasionally regard their strategic interests as more closely aligned with delay than with speed. The Sixth Amendment, however, does not protect such interests. Recognizing this, the motive test offers a new interpretation of Barker that gives both prosecutors and defendants incentives to do what they can to speed the trial process along. 
